\title{
DO WE LIVE IN A MARXIAN WORLD?
}

\author{
J. Agustín FRANCO \\ Department of Economics, Faculty of Business, Finance and Tourism, \\ University of Extremadura, Av. University 1, 10004 Cáceres, Spain
}

Received 03 September 2014; accepted 20 September 2015

\begin{abstract}
This paper proposes a scientific discussion from a Marxian-feminist point of view as a critical response to the European "austerity policies". Nowadays global inequalities are very relevant, particularly a proletarization process based on an increase in class struggle, growing inequalities, unsustainability and the transnational concentration of power and wealth. The neoliberal approach ignores Marx's theory and suggests that the Marxian view fails to explain the current economic system. However, I believe this to be a (dishonest) simplification of Marx's theory (because data is very clear). This misrepresentation has a negative effect on the overall validity and sustainability of several European policies, mainly distribution and migration policies. Consequently, some policy recommendations need to be readdressed, including from a feminist point of view.
\end{abstract}

Keywords: global labour exploitation, feminist view, inequality, class struggle, business irresponsibility.

JEL Classification: B51, B54, F01, F22, F66, J16.

\section{Introduction}

"In the era of globalization of production and employment, the reserve army of labour has drastically expanded beyond national borders. According to a recent report by the International Labour Organization (ILO), between 1980 and 2007 the global labour force grew by 63 percent. The report further shows that, due to worldwide urbanization and/or de-peasantization, the ratio of the active to reserve army of labour is less than 50\%, that is, more than half of the global labour force is unemployed" (Hossein-Zadeh 2014a).

This article focuses on a worldwide Feminist and Marxian ${ }^{1}$ condition known as Global Labour Exploitation (GLE) or "Exploitalization" (exploitation plus globalization), crossing genders, races, cultures, religions, generations and countries. GLE is defined as the transnationalization and financialization process of the labour exploitation, thus, an expansion phenomenon from the national scenario to the world one and from the real economy to

Corresponding author J. Agustín Franco

E-mail: franco@unex.es 
the financial one. It is a critical response to "austericide" policies in the European Union where this historical condition is discussed. The proletarization process is crucial to understand the Marxian-feminist view of the intensification of class struggle, growing inequalities, unsustainability, concentration of power and wealth and abolition of the Welfare State model. The Marxian perspective of global inequality has been discussed and dismissed by several authors. Some of them suggest that Marx's theory is not able to explain the current economic system (for instance, Milanovic 2012, 2013). Furthermore, some even deny the existence of class struggle. However, I would argue - together with other scholars - that this is an oversimplification of Marx's theory (e.g. Guerrero 2008; Navarro 2011; Hossein-Zadeh 2014b; Arrizabalo 2014). This misrepresentation has a negative impact on the overall validity and sustainability of some critical questions (distribution, migration and gender policies) and of the claims made by the European and global policy-makers.

There are three main questions related to the neoliberal policies in world and European Union. Firstly, the analysis of income distribution as a measure of global inequality from two components: difference in incomes within-country and between-country, i.e. the "class" and "location" components, respectively. "We can call the between country inequality "locational' because it depends on the differences of mean incomes between various places (countries), and the within inequality, 'class' inequality because it depends on different individuals, living in the same country, having different incomes and belonging to different social groups" (Milanovic 2012: 127).

Secondly, criticisms of the Marxist perspective based on the increasing importance of locational inequality since the $20^{\text {th }}$ century. So a new revolutionary subject is proposed: from proletarians to migrants (Milanovic 2012, 2013).

Thirdly, several neoliberal policy implications are proposed in growth, distribution and migration terms. These policies are mainly related to the ethical model of the "invisible hand" behaviour, next to a just Neo-Swiftian migration policy (Swift 1729). In other words, if the within-poor exploitation were intensified, the between-classes exploitation would be harder to identify.

Taking into account these ideas, two big paradoxes (or traps) can be detailed according to Sumner (2012). Briefly, we can talk of a "measurement paradox"2 when focus is on empirical evidence, and of a "migration paradox" when focus is on theoretical evidence. The first paradox (measurement) is supported by the fact that several measures of inequalities are not reliable. However, measurement is not the key (Sumner 2012: 21): “.. poverty research in the mainstream has been depoliticised by the 'measurement obsession'. Measurement is not the problem, however. The problem is embedding poverty research within an analysis that includes distribution, social differentiation and the process of economic development - in short, the political economy of poverty".

The second paradox (migration) holds that the most impoverished people are not migrants. Both traps have depoliticised the research of global inequality, income and wealth distribution (Sumner 2012). To be precise, Milanovic (2012) falls in the "migration paradox", while Milanovic (2013) falls in the "measurement paradox". In both paradoxes, global income inequality as the main factor is justified in order to explain the current weakness in the Marxian conception, specifically due to the disappearance of workers' solidarity from 
the 1850 s to the beginning of the $21^{\text {st }}$ century. He concludes that if "location determines to a large extent one's income is that it must be a world of huge migratory pressures because people can increase their incomes several fold if they migrate from a low mean income location to a high mean income location" (Milanovic 2012: 130).

This is the main Achilles' heel of the neoliberal argument when substituting "working classes" (a genuine political issue) for "migrants" (which are reduced to an accountancy issue, more related to demographical and technical topics). In other words, "working class" is a political subject, while "migrant mass" is mainly considered a political object - where corporations are the new political actors (politics is in the business men's hands). If the worker's identity is reinforced by the migrant condition then a new capitalist contradiction emerges: Are migratory flows an effect of the disaggregation of workers' solidarity and a cause of a major conscience of exploitation? How does the dynamic and interdependencies of this process of dis-alienation work? "These interdependencies operate at the level of 'deep structure' of economic process, as opposed to the surface appearance of events which are the normal focus of attention of economists" (Dow 1998: 43).

These topics will be discussed further on. On the one hand, the double problem of revolutionary subject is studied in two steps. First, the Marxian-feminist focus is exposed. Second, the question of migrants or proletarians will be addressed: Are they contradictory or are they two sides of the same coin? This issue is analysed from a transversal gender point of view. On the other hand, a theoretical framework is developed (GLE paradigm) related to some models of pseudo-solidarity and irresponsibility business (corruption, social bad practices and ecological unsustainability). Then, the literature about global labour exploitation according to several criterions is reviewed and linked to the "austericide" policy. Finally, the main policy recommendations and conclusions are listed.

\section{The global revolutionary class}

\subsection{The Marxian-feminist view}

What this paper seeks to emphasize is not the absence of surface feminist language, but the feminist foundations of Marx's thought. This paper focuses mainly on both the gender and economy dimensions as key to sustainable development. Awareness of femininity is the common substrate of any critical theory of capitalism, because it places the logic of life and sustainability (ethics of care) over the logic of death or unsustainability (performed by "Ideological Troika"): capitalism, Christianity (a Western-centrist vision) and patriarchy (Franco et al. 2012b).

Following van Staveren (2014), the 2008 market crash - and the Great Recession that followed the collapse - would not have happened with more women in the top of financial system. She analyzes this idea (the so-called "Lehman Sisters hypothesis") in three dimensions: Ethics and moral attitudes, leadership and risk aversion. Particularly, "experimental game theory has consistently shown than women are more cooperative than men. This suggests that women's reasoning in complex situations is more contextual than men's" (van Staveren 2014: 1004). 
However, according to the Communist Manifesto: "The bourgeois sees in his wife a mere instrument of production...He has not even a suspicion that the real point aimed at [by communists] is to do away with the status of women as mere instruments of production".

Moreover, Marx (1868) said "that great social revolutions are impossible without the feminine ferment. Social progress may be measured precisely by the social position of the fair sex".

Gilligan (1982) help us discover the true feminist character of Marx's work. She analyzes the different moral development of men and women. She notes that, in general, women are characterized by a worldview that emphasizes social relationships, the ethics of care and responsibility unto others and unto themselves and sustainability. Conflicts are resolved by contextualizing and taking into account each person's singularity. On the other hand, the male ethical view prioritizes individual and independent development, cultivating personal and professional success. Men are inclined to resolve conflicts in an abstract and legal way, through principles universally valid for any time, place and type of person ${ }^{3}$.

Using Gilligan's (1982) findings we can easily identify the main aspects of a feminist morality in Marx's economic reasoning. (Political) Economy is understood in a contextualized and historical manner. The means of production are understood as social network and not as mere commodities. It describes capitalism as a system of social networks and the historical struggle of social classes. This conflict is solved through a social revolution where everyone participates (both exploiters and exploited), without prescribing the destruction of anyone, through a collective leadership (only proletarian?). For this purpose the appropriate measures proposed are the abolition of exploitative labour conditions, the abolition of all class domination and the emancipation of the exploited class (we may ask ourselves if this is only the working class).

\subsection{Migrants vs. proletarians}

The most important issue revolves around an incomplete interpretation or over-simplification of the Marxian view. Can we state that we do not live in a Marxian world just because the inequality level between countries (location component) is now higher than the inequality inside each country (class component)? Milanovic $(2012,2013)$ does. If we accept this hypothesis, we are tacitly accepting three statements: 1) Migrants are a homogeneous group; 2) Migration is only understood between countries, but not between regions inside the same country (sub-national level migration); 3) Today some transnational corporations have more influence on international policies and outcomes than the sum of several democratic countries.

In addition, migrations from birth place (for economic reasons, such as fleeing poverty) could also be interpreted as an expression of social class migration (social mobility). The location component is the other side of the same "Marxian coin", known as class struggle.

According to the Communist Manifesto, the "revolutionary class" goes beyond the classification of the population in quintiles. The revolutionary class is formed by anyone and everyone who acquires a proletarian conscience, not matter if he/she is a worker or not. Nowadays the "revolutionary class" conscience is absent because labour (paid and unpaid) 
is not conceptualised in terms of alienation and exploitation. Consequently, there is a gap between perception and reality. To ignore the reality does not make it inexistent. But, can we talk of an emerging new conscience of the oppressed class? Is a new strategy emerging in the global scenario? Some interesting citizenship initiatives asking for more democracy exemplify these new social movements: Occupy Wall Street, 15M Spanish Movement, the Arab Spring, etc.

If we examine world income distribution, is it possible to refocus this global proletarization on migrant flows only? That is, could the subject of the revolutionary class be replaced from proletarians to migrants? The reasons for migration are not purely economic; they may also be political and environmental, according to the International Organization for Migration ${ }^{4}$. Can we consider migration as an element of a large exploitation of proletarians?

The argument that migration encourages the economic growth of poor countries is not longer valid. The international migrant remittances have been absorbed by the logic of financialization in the periphery. According to Hudson (2008: 316): "the political consequences of harnessing remittances are that the underlying causes of global poverty, inequality and underdevelopment are sidelined". Two implications can be derived from this 1) the importance of migration is reduced to an explicative factor and 2) the "collateral effect" of an eventual economic growth. In other words, some developing countries' average per capita income will increase despite the fact that the large majority of people remain poor. Migration does not invalidate Marx's view. In fact, they constitute a new expression of the historical process of capitalist accumulation: Workers vs. Workers (e.g. Frank 2001; Fraser 2014). Particularly, in the context of migratory flows and following Sassen (1999), states are playing the role of mediators between the capital and migrant labour forces.

The importance of migration is highly questionable. The migrant population (214 million) accounts for just $3 \%$ of the world population, or about $17 \%$ of poor people (UN 2009; Sumner 2012). This percentage has remained relatively stable over the first decade of the $21^{\text {st }}$ century. However, more than half of the global labour force is an involuntary member of the reserve army of unemployed (Hossein-Zadeh 2014a). Indeed "a good amount of industry is now more mobile than workers: Manufacturers can close a factory here and open another one there at the drop of a hat" (Frank 2001: 273).

According to UN (2009), there is a net migration of about 2.4 million people per year to the more developed regions, of which over $50 \%$ is directed at North America. Migration movements from less developed regions to more developed regions have explained the global migration patterns for almost half a century, but flows among developing countries have also been important. In that sense, the migrant growth rate in more developed regions between 1990-2010 has fallen from $14 \%$ to $9 \%$, whereas the rate in less developed regions has increased from $-2 \%$ to $+10 \%$.

Global wealth has grown mainly thanks to a greater integration of women into the labour market (Navarro 2011). One example at European level is Sweden in the 1960s, where the integration of women into the labour market was encouraged and brought about lower levels of immigration (Navarro 2013). This process was accompanied by childhood services and home care initiatives, as well as the promotion of the co-responsibility of men in housework. 
Even accepting migration as an explanatory factor to curb poverty, we must highlight the following: women account for $52 \%$ of all the immigrants in more developed regions (6\% more than this in less developed regions). Also, we can identify a double process: the international crisis of care (Benería 2008; Gálvez, Torres 2010; van Staveren 2014) and the impoverishment and feminization process of migrants and the working classes (UNFPA 2006).

Milanovic and Muñoz del Bustillo (2008) indicate that in Latin America, when the level of education held by children is greater than that held by adult women, the probability of labour market integration decreases. WEF (2014) studies the gender gap in four inter-connected dimensions: this gender gap is greater in the economic and political dimensions than in the educational and health dimensions, especially in poor countries.

Several studies show that immigrant workers in the Spanish domestic service account over the half of adults employed in this sector, most of which are women (see review in García-Moreno 2015). The level of qualification of immigrants in this sector is higher for the non-Spanish workers than their Spanish colleagues. For example, 54\% of Spanish employees working in domestic services failed primary school education, whereas $40 \%$ of Ecuadorians started or completed secondary education or higher and more than $90 \%$ enrolled in primary school education (Colectivo Ioé 2001). According the CECS (2011: 238-298) immigrants in Spain have occupied secondary market niches in uncomfortable, dangerous, precarious, low-prestige and low-paid working conditions.

Sarasúa (1994: 30-44) analyses the historical evolution of domestic service in Spain as a way of inserting the rural migratory population into the cities. This working force was mainly masculine in all European cities during the 18th century but became mostly female during the $19^{\text {th }}$ century. This was due in part to several factors easing migration (the work organization of families and the different access to the family resources of men and women), but mainly due to the characteristics of the labour market. In the middle of the $18^{\text {th }}$ century the Spanish labour market was not very diverse and was controlled by guilds, which limited the access to craftsmanship jobs. This explains why domestic service was mainly taken up by men. However, at the end of the $18^{\text {th }}$ century and beginning of the $19^{\text {th }}$ century the masculine labour market became more diverse (excluding women on the basis of a strict sex-based division of work), allowing men to work in the army, administration, public works, etc. The increase of women in domestic service is therefore an indirect result of men abandoning it in favour of other job offers and the direct result of a labour market that denied women the access to skill-required jobs, thus ensuring they stayed in domestic service.

Indeed, patriarchal economy can be seen as an iceberg: keeping the privileged part of the economy afloat - commercial and paid - requires a series of invisible activities which are mainly performed by women. In Spain, the CGT (2004) estimates that $80 \%$ of the two thirds of the market which are invisible (unpaid black market) is care service undertaken mainly by women (which accounts for roughly 14 million jobs). On the other hand, only a third part of the labour market is visible (paid work) in the official statistics.

According to the International Labour Organization (ILO 2015), domestic workers in the world (53 million) accounts $83 \%$ of women and only $9 \%$ of them have the same 
employment protection legislation than other workers. Only 17 countries (5 European countries: Germany, Italy, Ireland, Switzerland, Finland) have ratified the C189-Domestic Workers Convention that it entered into force on 05/09/2013.

All these situations are an expression of the hidden feminized side of the global exploitation process (Orozco 2005; Federici 2004; van Staveren 2010; Fraser 2014; García-Moreno 2015). All these situations are an expression of an invisible, strong (financial, business, corporate) global process that lacks in solidarity.

Finally, we can try to define the "global revolutionary class" as a near synonym of the global protester movements against the neoliberal policies and lack of democracy (Ortiz et al. 2013), from 15M Spanish Movement, YoSoy132 Mexican Movement, Occupy Wall Street, Femen international feminist movement to the new advances and alliances of the European left-wing parties as Syriza in Greece and Podemos in Spain. This global revolutionary class is near to others explanations as the new alliances between managerial and popular classes by Duménil and Lévy (2011: 73-89,2014) or some features of the economy of the Collaborative Commons (Rifkin 2014; Taifa Seminary 2013). Particularly, Rifkin (2014: 23) says that "the democratization of innovation and creativity on the emerging Collaborative Commons is spawning a new kind of incentive, based less on the expectation of financial reward and more on the desire to advance the social well-being of humanity".

\section{Theoretical framework}

\subsection{Global non-solidarity process, unsustainability and GLE}

Digging deeper into the latent idea of "solidarity" and "responsibility" - understood in international cooperation projects and business strategies - four basic models can be identified. Table 1 shows the main solidarity models and its most remarkable features. The conventional model of "development cooperation" would be the most advanced pseudosolidarity approach, although without dispensing with neoliberal characteristics and therefore rooted in the maintenance of the established order. It is still a model which does not place the focus on universal solidarity based on equity and justice, rather than on capitalism, neoliberalism and freedom without exploitation.

Table 1 allows us to analyze the hidden mechanisms of the GLE by Figure 1 (adapted from Arnold, Valentin 2013). It summarizes the main strategies of exploitation (of domination or hegemonic) characterizing the GLE model based on "philanthrocapitalism" or "market populism" (McGoey 2012; Frank 2001) ${ }^{5}$. In fact, false solidarity or the "devil's ethics" and "good slave" ethics (e.g. Corporate Social Responsibility (CSR), Base Of Pyramid (BOP) ${ }^{6}$, Official Development Aid). Why pseudo-solidarity? Because the international trade rules are the real obstacle to development. In words attributed to Eduard Munch [1863-1944]: "The rich man who gives, steals twice over. First he steals the money and then the hearts of men".

The three main axes are the following: 1) Western economic rationality (utilitarian, non-procedural and parametric, homo economicus' cold rationality); 2) Empowerment of people who benefit from solidarity programs; 3) Accessibility of receptors to opportunities for their own economic self-management. 
Table 1 . Hierarchy of global solidarity models

\begin{tabular}{|c|c|c|c|c|}
\hline \multirow[t]{2}{*}{ Characteristics } & \multicolumn{3}{|c|}{$\begin{array}{c}\text { PSEUDO-SOLIDARITY/RESPONSIBILITY } \\
\text { (acceptance and/or justification of inequality and } \\
\text { exploitation) }\end{array}$} & \multirow{2}{*}{$\begin{array}{c}\begin{array}{c}\text { SOLIDARITY } \\
\text { (equality, freedom } \\
\text { without exploitation) }\end{array} \\
\text { Classless society }\end{array}$} \\
\hline & Show & Campaigns & Cooperation & \\
\hline Key concept & Market & Aid & False development & Social transformation \\
\hline Objective & Statu quo & Humanitarian & Legitimation & Social change \\
\hline Idea of poverty & Disgrace & Stigma & Failure of system & $\begin{array}{l}\text { Freedom without } \\
\text { exploitation }\end{array}$ \\
\hline Metodology & Festival & Information & NGOs & Non-alienation \\
\hline Approach & Emotional & Moral & Scholar knowledge & Economic democracy \\
\hline Monitoring & No monitoring & Only economic & $\begin{array}{l}\text { Project } \\
\text { (technical } \\
\text { dimension) }\end{array}$ & $\begin{array}{l}\text { Processes of } \\
\text { monitoring } \\
\text { (social dimension) }\end{array}$ \\
\hline Ethics & Postmodernism & Utilitarianism & Dependence & Mutual support \\
\hline Benefactor & $\begin{array}{l}\text { Consumption of } \\
\text { solidarity }\end{array}$ & Compassion & Awareness & $\begin{array}{l}\text { Emancipation } \\
\text { (justice) }\end{array}$ \\
\hline Beneficiary & Commodity & Beneficence & Participation & \\
\hline Business model & Charity & Philanthropy & $\begin{array}{l}\text { Foreign Investment, } \\
\text { ODA, internat. trade }\end{array}$ & Non-capitalist \\
\hline $\begin{array}{l}\text { Idea of } \\
\text { responsibility }\end{array}$ & $\begin{array}{l}\text { Market } \\
\text { rationalization }\end{array}$ & $\begin{array}{l}\text { Moralization } \\
\text { and ethical } \\
\text { leadership }\end{array}$ & $\begin{array}{l}\text { Reconceptualization } \\
\text { and professio- } \\
\text { nalization }\end{array}$ & $\begin{array}{l}\text { Political economy } \\
\text { restructuring }\end{array}$ \\
\hline
\end{tabular}

Source: our own from Aranguren (1998) and Herzig and Moon (2013).

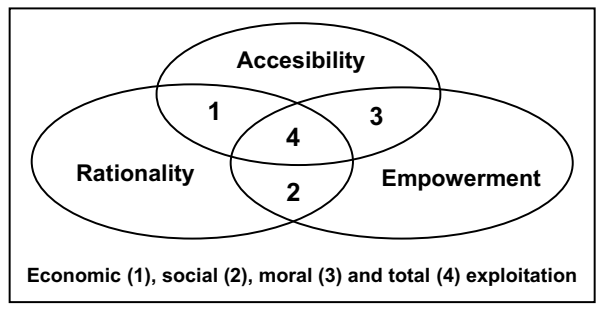

Fig. 1. Global Labour Exploitation models and strategies

According to Gómez and Franco (2014) these axes can help us analyze the hidden agenda that promotes labour exploitation. They identify the set of practices of cooptation and latent meanings behind the funding of Development Cooperation projects and the financial support of other "alternative" initiatives such as microloans or fair trade.

The first axis is related to the funding of development projects which tend to imply a transfer of its economic-oriented rationale (competition in order to gain funding, justification of expenditure, record of accounts) in two ways: 1) Demanding that the beneficiary population adopts capitalist practices and 2) promoting a capitalist idea of time (measured in working hours) which encourages predictability, future planning and accountability for past actions. This fosters the substitution or hybridization of agricultural, seasonal and communal practices. 
The second axis is related to the commercialization of solidarity. This means changing the concept of solidarity labour - based on reciprocity and intrinsic values/duties/obligations of communal living - to an idea of work as a paid commodity.

The third axis is related to an expansion of capitalism through so-called "alternative" funding initiatives. These initiatives are softer and modified capitalist options which promote an equitable distribution of income and wealth.

At the intersection of each axis a GLE space is generated with economic (1), social (2) and moral (3) dimensions. The overlap of the three axes leads to an integral exploitation or "exploitalization" (4) where the previous three exploitations types are combined.

"Economic exploitation" (apolitical) refers to the implementation of accessible business projects for the beneficiary population, but with no effects of empowerment. It is especially visible in the financing methods for projects that stigmatize poverty. For the sake of the homo economicus' rationale, a deeper understanding and other visions (ecological, feminist) are ignored. Finally the beneficiary population is driven to repeat Western patterns (consumerism, contamination, industrialization, increasing salaried people), including the analysis of the BOP (Arnold, Valentin 2013) based on a neoliberal idea of solidarity, sustainability and cooperation (McGoey 2012).

"Social exploitation" (political) is the confluence of non-inclusive projects and authoritarian empowerment mechanisms (capitalist, socialist or any other authoritarian regime). "Exclusive projects" are not accessible to the public, except to an elite or group that determines the main features. These projects are normally negotiated with corrupt public representatives. Moreover, sweetened versions of capitalism are included ("good capitalism"): fair trade, responsible consumption, microloans, green economy...

Empirical evidence seems to show that these "social economy" initiatives do not substantially improve the welfare of the beneficiary population, but help internalize capitalist values through an "entrepreneur ideology" (Milanovic, Muñoz del Bustillo 2008; Narayan et al. 2000; Banerjee, Duflo 2011).

"Moral exploitation" (ethical, ideological) operates on a more unconscious level. It is generated, for example, through accessible business projects with an empowerment bonus, but whose financial support is essentially charitable. The unreachable horizon of $0.7 \%$ is a good reflection of this exploitation type. Between Official Development Aid and External Debt there is moral balance deficit (blame): More money flows from South to North through external debt or through the unjust rules of international trade that from North to South through cooperation projects. Following Oxfam (2002: 5): "In their rhetoric, governments of rich countries constantly stress their commitment to poverty reduction. Yet the same governments use their trade policy to conduct what amounts to robbery against the world's poor. When developing countries export to rich country markets, they face tariff barriers that are four times higher than those encountered by rich countries. Those barriers cost them $\$ 100$ billion a year - twice as much as they receive in aid".

Moreover, the Official Development Aid related to gender is very symbolical, including enormous deficiencies in gender policies in particular (Gómez, Franco 2014) and in poverty policies in general: The major proportion of poor people has remained constant in twenty years, $75 \%$ of the world's poorest people lived in countries that relied on aid for less than 2\% of their income from 1990 to 2009 (Glennie 2012). 
This is not only applicable to these concepts. It is also interesting to highlight the role played by flows of illicit capital from underdeveloped countries to tax havens controlled by developed countries, and the net flow (for the benefit of the developed nations) of private capital flows (García-Arias 2015). In this scenario economic justice is anecdotal. Solidarity as a consumer product is the last aim.

Moral sanction against exploited people is the Neoliberal Manifesto: there are not impoverished people, only poor people. As a corollary, it must be noted that a historical and social problem (capitalist relationships) is substituted for a personal and private blame (my habits, my ethnicity, my religion, my gender, my ignorance, my culture). A double consciousness is generated which diverts attention, energy and resources that would form any kind of resistance to any system of domination. An example of this anti-colonial and anti-capitalist resistance which has been taking place for more than five centuries can be seen in the treatment of Native Americans, especially women, because of their ties to the land, nature and local religions (Federici 2004).

"Full exploitation" occurs when any two of the abovementioned exploitation types converge. The theoretical model that hides GLE is a neoliberal approach known as Corporate Social Responsibility (CSR). This neoliberal approach has a main objective for CSR: it goes from human dignity and Human Rights (Welfare State) to private-profit and voluntary charitable actions; from welfare to philanthropy; from dignity to alms; from economic justice (political key) to Humanitarian Aid/Cooperation (technical key). The clearest example of this systemic exploitation is the dubious contribution of the Millennium Development Goals, which have been a conceptual and programmatic kick, a strong commitment to the neoliberal system and a reduction of public policies (Pérez de Armiño 2011). An even clearer example is the infamous neoliberal invention of CSR or business ethics ideology. This is just a euphemism for global irresponsibility (more elegantly named as "philanthrocapitalism" or how capitalism promotes the public good through individual economic enrichment), a hidden mechanism to enforce the GLE or exploitalization.

\subsection{Global irresponsibility and GLE}

Against the conventional model of Corporate Social Responsibility (CSR v. -1.0 model or "three lies model", because it is not responsible, social nor corporate), a more complete model can be developed: the CSR 2.0 model. The CSR 2.0 model is the model of Class Social Resistance or also known as Emancipatory Social Resistance (Fig. 2).

CSR -1.0 model is insufficient because it does not account for the empirical evidence proving the systematic lack of corporate responsibility nor their hidden agenda. It is best explained by the CSR 2.0 model. Perhaps the main drawback of the CSR -1.0 model is its lax ethical model, which ignores the debate on voluntary vs. mandatory responsible practices, and therefore does not progress towards a comprehensive legislative and judicial development (including inspections and sanctions for offenders and fraudsters). It also ignores the intrinsic injustice of capitalist dynamics, which exacerbate the effects of the accumulation process through recurrent systemic crises, thus increasing social polarization, intolerable inequalities and irresponsibility. Its human behaviour model is the homo economicus. 


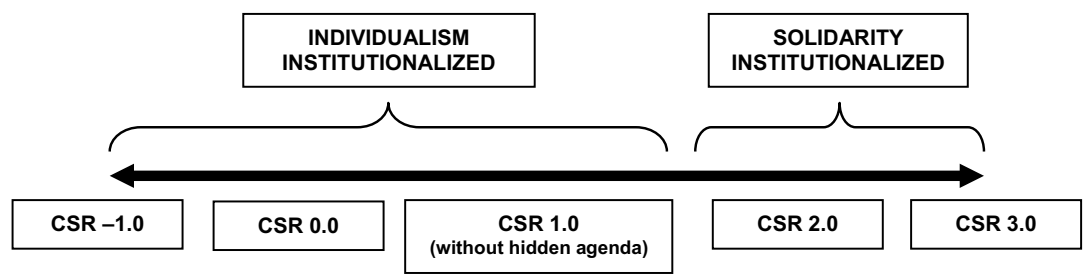

Fig. 2. Evolutive scheme of CSR models from the Marxian dis-alienation process

The basic or "baseline" model would be the CSR version 0.0 model (Citizen Social Reciprocity), which simply defines the meaning of a minimum social reciprocity among people, what Cortina (2011) names homo reciprocans and Rifkin (2014) as homo empathicus. A step further would be the CSR 1.0 model. It brings to light the hidden agenda of the neoliberal model (version -1.0) or the Capital Sociopath Irresponsibility (CSI) model. Three hidden ethical principles related to the markets can be identified from this model to later define the CSR 2.0 model (Fig. 3): The "responsibility" fallacy or irresponsibility principle; the "social" fallacy or distrust principle and the "corporate" fallacy or non-existence principle ("I see dead markets", to paraphrase The Sixth Sense's main character). These three hidden principles constitute the ethical infrastructure related to the methodological infrastructure of neoclassical theory according to Arnsperger and Varoufakis (2006): instrumentalism, individualism and equilibrium theory, respectively. Deep ethical irresponsibility is hidden by the "responsibility" discourse that reflects the human rationality as instrumental to the process of maximization. Ethical distrust is hidden by the "social" discourse that shows the fundamental contradiction based on an individualistic behaviour model. Finally, the non-existence principle is hidden by the corporate governance discourse and the entrepreneurship ideology that reflect the unreality of the harmony and utopia of the free market, always in an equilibrium situation, without class struggle, the narrative of the win-to-win.

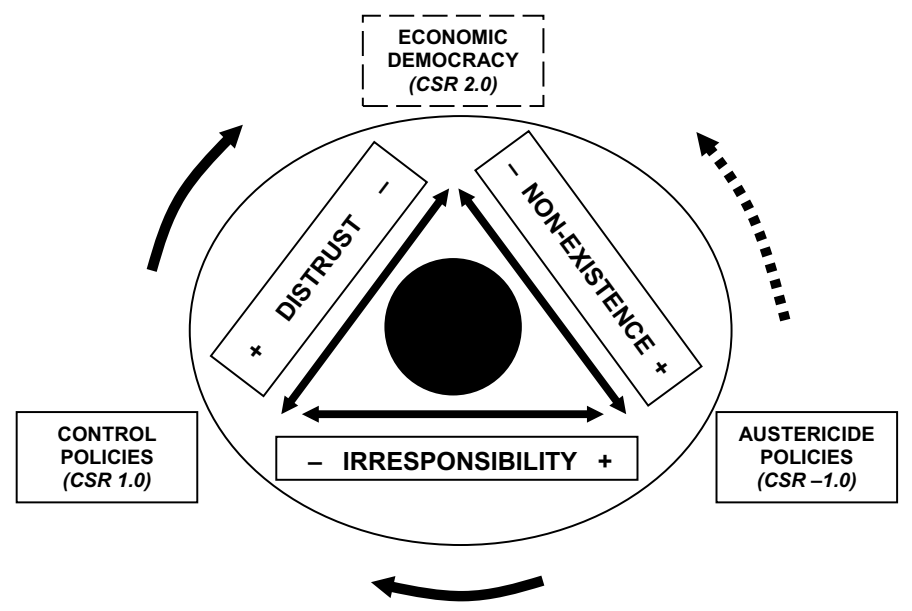

Fig. 3. Bermuda Triangle of CSR models 
CSR 2.0 incorporates the concepts of social class and class struggle that characterize capitalist dynamics. In this sense, this model analyses several main questions: index of corruption, fraudulent (financial) practices, breach of human rights, tax evasion levels, volume of transactions in tax havens, gender discrimination rates, historical evolution of salaries, level and scope of public policies, magnitude of the "revolving doors" effect between political and economic powers, lack of transparency in financial investments, use of double standards in technology (less contaminant in the North and more contaminant in the South), etc.

CSR 2.0 includes the ethical, ecological and social concerns that arise from the struggle and resistance of the most disadvantaged and excluded people. From this perspective, CSR 2.0 is an updated version and renewal of class consciousness, class solidarity, mutual aid and support. A model that includes the emancipatory tradition: from the earlier solidarity funds for the unemployed (les caisses de résistance) to the most recent initiatives of Alternative and Solidarity Economy (ethical finance, de-growth, progressive ecology, basic income, feminist economics, etc.) which are orientated at institutionalising and strengthening democratic economy (e.g. Fraser 2014), beyond the formal democracy of neoliberalism and other dangers of cooptation (e.g. see website of the Intercontinental Network for the Promotion of Social Solidarity Economy: www.ripess.org). Because "neoliberalism is incompatible with the expansion of democracy into key areas of social life" (Ayers, Saad-Filho 2015).

The logical evolution of CSR 2.0 model is the CSR 3.0 model: Complete Social Revolution model. This model presupposes the overcoming of capitalist society, relations of exploitation, domination, alienation and unsustainability. The construction of an egalitarian, classless and consolidated economic democracy based on freedom without exploitation and solidarity relations. Figure 2 schematically summarizes various CSR models on a scale of ideological and institutional approaches: individualism and solidarity or, in other words, freedom with or without exploitation. As can be seen, the basic model, CSR 0.0, which corresponds to the basic sense of reciprocity, clearly falls in the individualism framework because, although it involves the human capacity to defer the reward, it does not deny it but searches it. Conversely, the absence of personal reward is the main feature of responsibility models, that is, solidarity and sustainability (see Table 1). The transition process from each CSR model to the next is a dis-alienation process, a gradual process of consciousness of the exploitation mechanisms, in particular, the levels of exploitation described above (economic, social, moral and total).

According to the theoretical framework above, we can design a strategy of political, ethical and institutional development that contributes to building a better society. Thus, not only do we integrate the analysis of the CSR models in a new paradigm, but the possible lines of political action are described according to the pursued objectives.

At this point the question we must ask ourselves is how to establish the dynamic relationship between the triad of principles that form the Bermuda Triangle of CSR, where all the supposed benefits and virtues of the free market disappear. Using another metaphor, we can talk about the Black Hole of CSR that inwardly attracts the radiant light of the free market and the invisible hand (Fig. 3). Located away from this black hole is what we call 
the "sixth sense of CSR". The first five senses or meanings correspond to the five versions of CSR discussed above.

Figure 3 shows the interaction between the hidden principles of CSR and the different economic legislation and policy measures that can be taken. The three following points can be discussed in this theoretical scheme. Regarding the right lower corner (CSR -1.0): If the irresponsibility is maximum then the lack of markets will be too. In this corner the overall level of distrust is intermediate, thus, austerity policies are implemented because they provide the most benefit for the dominant classes. From this stage we can move in two opposite directions towards CSR 2.0 model:

- Left: The lower left corner (CSR 1.0). A long and gradual way, resisting the opposition of the powerful, and therefore more controversial.

- Right: The upper corner (CSR 2.0). A shorter and more direct way, unlikely too, but more peaceful.

Both directions lead to the creation of democratic institutions and structures, including economic democracy as a prerequisite for political democracy in order to the abolish neoliberalism (Ayers, Saad-Filho 2015). In the longest direction towards economic democracy there is an intermediate stage (CSR 1.0) in which distrust of markets is growing. This situation causes a decrease in the levels of irresponsibility through various "control policies". For example, mandatory CSR practices, progressive tax law, international law to discourage financial speculation, etc. In this corner the lack of existence of markets is in an intermediate range: there is a significant act of faith in the authority of "the markets".

Finally, an important process begins in the most advanced social stage (CSR 2.0): the genesis of the conditions for the consolidation of economic democracy. In this stage both "distrust" and "non-existence" levels are very low, so the level of irresponsibility is intermediate. In other words, without leave to believe in ghosts, our "confidence" in the "markets" increases (our sixth sense is sharpened and the times we see "dead markets" are multiplied). This encourages a socially acceptable level of irresponsible business behaviour, particularly among the powerful, allowing a less unequal exchange (smoothing conflict) in the negotiation between the exploiting and exploited classes. Without co-responsibility between supplier and consumer there is not market ("dead market" or disappeared market or ghost market), there is only abuse (Navarro 2012), a Darwinian-style economics. Additionally, De Sebastián (2000) pointed out that the business fusions in a productive sector restrict the laws of market. Managerial capitalism substitutes the invisible hand principle of free markets by the visible hand of a planned system.

Some hazards. According to Figure 3, we can fall into a vicious circle if we go from the CSR 2.0 model to the side of labour exploitation (or maximum negation of the existence of markets), that is, the CSR -1.0 model. This decline is faster than the degradation of "confidence" in the markets. Finally, a situation where irresponsibility is high and social indignation insufficient can again be observed.

A more sophisticated version of this circular model (Fig. 3), taking into account the experience of these relapses, would be a spiral pattern: centrifugal to decrease capitalism or centripetal to intensify it. As a corollary: social conflict is undeniable. The following phenomenon can be observed: in one way or another, this economic system is not the end 
of history (in a Fukuyamian sense). We can leave it if our horizon is the utopia of the CSR 3.0 model. The best way is to reach the stage of economic democracy (CSR 2.0). To achieve it, the revolutionary redefinition of solidarity and alternative economy initiatives is indispensable (Franco 2015). Following Arrizabalo (2014: 78-83), the emancipatory tradition of Marxism precludes any discussion about the desirability of any public policy because we would continue talking about the desirability of a better way of exploitation. Although transitional demands to improve the living conditions of workers are a different issue (which shows two things: the importance of independent unions and the impossibility of capitalism without increasing exploitation). Such transitional demands imply four basic criterions to describe distinct "alternative" proposals as social transformers (Etxezarreta 2012; Taifa Seminary 2013): Collective property of the means of production, a communitarian-type productive system and an equitable distributive system, horizontal management of power and promotion of common good and social and individual welfare.

In sum, according to the Communist Manifesto, the aim is to build the consciousness of the revolutionary class. The target is the abolition of exploitation relations that are inherent to capitalism.

\section{Empirical evidence of Global Labour Exploitation}

Labour exploitation is one of the main axes of capitalism. It can be measured by unemployment rates or environmental degradation indexes. Even full employment does not exist in expansive economic phases (Buendía, Palazuelos 2014). Nowadays in a globalization context, the "natural" evolution of capitalism is the neoliberal system, where the global labour exploitation is the main characteristic. Empirical evidence is not lacking. Table 2 summarizes the most important characteristics of literature related to GLE and types of exploitation according to three analysis levels: economic or structural, environmental and social. These levels are the pillars of the abovementioned liberal CSR (or Corporate Social Irreponsibility, according to Herzig, Moon 2013).

The basic categories of these levels are the following: gender, finance, poverty, inequality, sustainability and social welfare. The "gender variable" is the main socio-economic category (Burchardt 2008; Gálvez, Torres 2010; WEF 2014), although traditionally it has remained hidden. Gender as the hidden abode of the patriarchal capitalism is transversal to the other categories (Fraser 2014).

A historical view of the building of global capitalism from feudalism is detailed by Federici (2004). She analyses the systemic violence against women as a tool of creation and development of capitalism from feudal times. This gender violence is an invisible central point in capitalist relationships. GLE is in the origin of capitalism and it spreads throughout all of the system. Violence against women is GLE by means of unpaid work (home, family, cares). The final step is crisis management or "shock doctrine" (Klein 2008). Several types of exploitation are identified: anti-union practices, failures of CSR (global non-responsibility and corrupt practices), forced labour, labour exploitation and low wages.

At a financial level, neoliberal globalization encourages speculative behaviour (Agüera, García-Arias 2000; Medina, Cascante 2011; Navarro, Torres 2012; Herzig, Moon 2013). 
Table 2. Review of studies related to the Global Labour Exploitation from 2000 to 2013

\begin{tabular}{|c|c|c|c|c|c|}
\hline $\begin{array}{l}\text { Dimen- } \\
\text { sion }\end{array}$ & $\begin{array}{l}\text { Level of } \\
\text { Study }\end{array}$ & Author & Main topic & $\begin{array}{l}\text { Type of } \\
\text { analysis }\end{array}$ & Main data on GLE \\
\hline \multirow{4}{*}{ 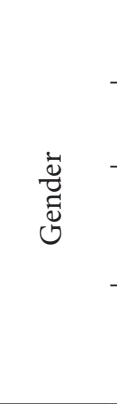 } & Social & $\begin{array}{l}\text { Gálvez and } \\
\text { Torres (2010) }\end{array}$ & Financial crisis & $\begin{array}{l}\text { Statisti- } \\
\text { cal }\end{array}$ & Crisis capitalist: gender gap. \\
\hline & Social & WEF (2014) & Gender Gap & $\begin{array}{l}\text { Statisti- } \\
\text { cal }\end{array}$ & $\begin{array}{l}\text { Ranking of gender gap in sev- } \\
\text { eral dimensions. }\end{array}$ \\
\hline & Social & $\begin{array}{l}\text { Burchardt } \\
(2008)\end{array}$ & $\begin{array}{l}\text { Female work in } \\
\text { UK }\end{array}$ & $\begin{array}{l}\text { Statisti- } \\
\text { cal }\end{array}$ & $\begin{array}{l}\text { Non-paid work: } 75 \% \text { of low- } \\
\text { income group vs. } 20 \% \text { of high- } \\
\text { income group. }\end{array}$ \\
\hline & $\begin{array}{l}\text { Struc- } \\
\text { tural }\end{array}$ & Federici (2004) & $\begin{array}{l}\text { Historical origin } \\
\text { of capitalism }\end{array}$ & $\begin{array}{l}\text { Histori- } \\
\text { cal }\end{array}$ & $\begin{array}{l}\text { Structural violence against } \\
\text { women as origin of capitalism } \\
\text { from feudal times. }\end{array}$ \\
\hline \multirow{4}{*}{ 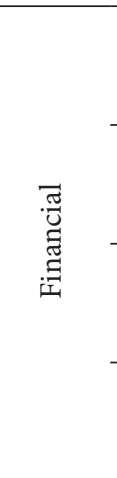 } & Social & $\begin{array}{l}\text { Medina and } \\
\text { Cascante } \\
\text { (2011) }\end{array}$ & $\begin{array}{l}\text { Financial specula- } \\
\text { tion }\end{array}$ & $\begin{array}{l}\text { Statisti- } \\
\text { cal }\end{array}$ & Food crisis and business profits. \\
\hline & Social & $\begin{array}{l}\text { Navarro and } \\
\text { Torres }(2012)\end{array}$ & $\begin{array}{l}\text { Financial system } \\
\text { and irresponsi- } \\
\text { bility }\end{array}$ & $\begin{array}{l}\text { Institu- } \\
\text { tional }\end{array}$ & Social welfare and Tax havens. \\
\hline & $\begin{array}{l}\text { Struc- } \\
\text { tural }\end{array}$ & $\begin{array}{l}\text { Franco and } \\
\text { Cascante } \\
(2012)\end{array}$ & $\begin{array}{l}\text { Financial specula- } \\
\text { tion and unsus- } \\
\text { tainability }\end{array}$ & $\begin{array}{l}\text { Statisti- } \\
\text { cal }\end{array}$ & $\begin{array}{l}\text { Speculative behaviour and } \\
\text { hunger. }\end{array}$ \\
\hline & $\begin{array}{l}\text { Struc- } \\
\text { tural }\end{array}$ & $\begin{array}{l}\text { Agüera and } \\
\text { García-Arias } \\
(2000)\end{array}$ & $\begin{array}{l}\text { Globalization and } \\
\text { speculative be- } \\
\text { havior }\end{array}$ & $\begin{array}{l}\text { Theo- } \\
\text { retical }\end{array}$ & $\begin{array}{l}\text { Financial markets regulation: } \\
\text { Financial Transaction Tax on } \\
\text { Foreign Exchange. }\end{array}$ \\
\hline \multirow{4}{*}{$\begin{array}{l}\hat{D} \\
\stackrel{0}{0} \\
0\end{array}$} & Social & $\begin{array}{l}\text { Milanovic and } \\
\text { Muñoz del } \\
\text { Bustillo (2008) }\end{array}$ & $\begin{array}{l}\text { Income distribu- } \\
\text { tion } \\
\text { and social budget } \\
\text { in Latin-America }\end{array}$ & $\begin{array}{l}\text { Statisti- } \\
\text { cal }\end{array}$ & $\begin{array}{l}\text { Universal programs: greater } \\
\text { redistributive effect than poor- } \\
\text { oriented policies. }\end{array}$ \\
\hline & Social & $\begin{array}{l}\text { Narayan et al. } \\
(2000)\end{array}$ & $\begin{array}{l}\text { Poverty, inequali- } \\
\text { ty and unemploy- } \\
\text { ment in South } \\
\text { countries }\end{array}$ & $\begin{array}{l}\text { Statisti- } \\
\text { cal }\end{array}$ & $\begin{array}{l}\text { Problems of social cohesion: } \\
\text { lack of economic opportunities, } \\
\text { forced migration. }\end{array}$ \\
\hline & Social & $\begin{array}{l}\text { Consumers } \\
\text { International } \\
(2010)\end{array}$ & $\begin{array}{l}\text { Adoption of CSR } \\
\text { by European su- } \\
\text { permarkets }\end{array}$ & $\begin{array}{l}\text { Empiri- } \\
\text { cal }\end{array}$ & $\begin{array}{l}\text { Voluntary CSR framework vs. } \\
\text { Human Rights approach based } \\
\text { on legal obligations. }\end{array}$ \\
\hline & $\begin{array}{l}\text { Struc- } \\
\text { tural }\end{array}$ & $\begin{array}{l}\text { Iglesias and } \\
\text { Badenes (2011) }\end{array}$ & $\begin{array}{l}\text { Legitimation of } \\
\text { capitalism }\end{array}$ & $\begin{array}{l}\text { Statisti- } \\
\text { cal }\end{array}$ & $\begin{array}{l}\text { CSR practices legitimize capi- } \\
\text { talist model. }\end{array}$ \\
\hline \multirow{4}{*}{ 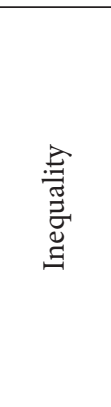 } & Social & $\begin{array}{l}\text { Milanovic } \\
(2012,2013)\end{array}$ & $\begin{array}{l}\text { Global inequality } \\
\text { in the distribution } \\
\text { of income }\end{array}$ & $\begin{array}{l}\text { Statisti- } \\
\text { cal }\end{array}$ & $\begin{array}{l}\text { Structures of inequality. Forced } \\
\text { migration increases. }\end{array}$ \\
\hline & Social & $\begin{array}{l}\text { Pérez de Ar- } \\
\text { mino (2011) }\end{array}$ & $\begin{array}{l}\text { Factors of neolib- } \\
\text { eral globalization }\end{array}$ & $\begin{array}{l}\text { Statisti- } \\
\text { cal }\end{array}$ & $\begin{array}{l}\text { Globalization has laid world } \\
\text { food crisis. }\end{array}$ \\
\hline & Social & Maravall (2013) & $\begin{array}{l}\text { Governments, } \\
\text { public policies } \\
\text { and elites }\end{array}$ & $\begin{array}{l}\text { Econo- } \\
\text { metric }\end{array}$ & $\begin{array}{l}\text { Governments (left-right) and } \\
\text { inequalities in OECD. }\end{array}$ \\
\hline & $\begin{array}{l}\text { Struc- } \\
\text { tural }\end{array}$ & $\begin{array}{l}\text { Guerrero } \\
(2008)\end{array}$ & Social inequality & $\begin{array}{l}\text { Theo- } \\
\text { retical }\end{array}$ & Labour theory of value. \\
\hline
\end{tabular}


End of Table 2

\begin{tabular}{|c|c|c|c|c|c|}
\hline $\begin{array}{l}\text { Dimen- } \\
\text { sion }\end{array}$ & $\begin{array}{l}\text { Level of } \\
\text { Study }\end{array}$ & Author & Main topic & $\begin{array}{l}\text { Type of } \\
\text { analysis }\end{array}$ & Main data on GLE \\
\hline \multirow{4}{*}{ 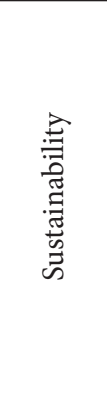 } & $\begin{array}{l}\text { Environ- } \\
\text { mental }\end{array}$ & $\begin{array}{l}\text { O'Connor } \\
(1998)\end{array}$ & $\begin{array}{l}\text { Capitalism vs. } \\
\text { Sustainability }\end{array}$ & $\begin{array}{l}\text { Theo- } \\
\text { retical }\end{array}$ & $\begin{array}{l}\text { Several models } \\
\text { of "sustainability". }\end{array}$ \\
\hline & $\begin{array}{l}\text { Environ- } \\
\text { mental }\end{array}$ & $\begin{array}{l}\text { SEO/BirdLife } \\
\text { and WWF } \\
(2010)\end{array}$ & $\begin{array}{l}\text { Growth model } \\
\text { and agrarian re- } \\
\text { sources }\end{array}$ & $\begin{array}{l}\text { Statisti- } \\
\text { cal }\end{array}$ & $\begin{array}{l}\text { Correlation between higher } \\
\text { subsidies and environmental } \\
\text { degradation in EU. }\end{array}$ \\
\hline & $\begin{array}{l}\text { Environ- } \\
\text { mental }\end{array}$ & $\begin{array}{l}\text { Franco et al. } \\
\text { (2012a) }\end{array}$ & $\begin{array}{l}\text { Sustainability vs. } \\
\text { CAP }\end{array}$ & $\begin{array}{l}\text { Multicri- } \\
\text { teria }\end{array}$ & $\begin{array}{l}\text { Common Agriculture Policy } \\
\text { penalizes more sustainable } \\
\text { farms. }\end{array}$ \\
\hline & $\begin{array}{l}\text { Struc- } \\
\text { tural }\end{array}$ & Jackson (2011) & Climate change & $\begin{array}{l}\text { Empiri- } \\
\text { cal }\end{array}$ & $\begin{array}{l}\text { Carbon emissions and inequali- } \\
\text { ties. }\end{array}$ \\
\hline \multirow{3}{*}{ 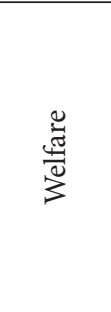 } & $\begin{array}{l}\text { All } \\
\text { levels }\end{array}$ & $\begin{array}{l}\text { Taifa Seminary } \\
\text { (several years) }\end{array}$ & $\begin{array}{l}\text { Mechanisms of } \\
\text { inequality }\end{array}$ & $\begin{array}{l}\text { Theo- } \\
\text { retical }\end{array}$ & $\begin{array}{l}\text { Public policies and social } \\
\text { welfare. }\end{array}$ \\
\hline & Social & $\begin{array}{l}\text { Navarro (2011, } \\
\text { 2013) }\end{array}$ & $\begin{array}{l}\text { Neoliberal poli- } \\
\text { cies vs. Welfare } \\
\text { State }\end{array}$ & $\begin{array}{l}\text { Statisti- } \\
\text { cal }\end{array}$ & $\begin{array}{l}\text { Low wages. Alliance of classes. } \\
\text { Corporations vs. democracy. }\end{array}$ \\
\hline & $\begin{array}{l}\text { Struc- } \\
\text { tural }\end{array}$ & $\begin{array}{l}\text { García-Arias } \\
\text { et al. }(2013)\end{array}$ & $\begin{array}{l}\text { Neoclassical poli- } \\
\text { cies undermine } \\
\text { periphery }\end{array}$ & $\begin{array}{l}\text { Histori- } \\
\text { cal }\end{array}$ & $\begin{array}{l}\text { Democratic deficit in EU. } \\
\text { Globalized neofeudalism. }\end{array}$ \\
\hline
\end{tabular}

Source: Our own from several authors.

Today, financial speculation is the best example of labour exploitation, rejecting Ricardo's famous comparative advantages theory.

At a poverty level, the unemployment rates have negative social effects, a decrease in social cohesion through lack of economic opportunities which leads to forced migration (Narayan et al. 2000). Moreover, the N-S Gap is increasing. The "debt logic" has economic supremacy (Ramos 2006). This topic is an example of the fallacy related to CSR, it has a role of lending support and legitimacy to capitalism (Iglesias, Badenes 2011). The neoliberal CSR is more related to the public/private partnerships and all their inherent "do-the-rightthing" schemes of tender human-face capitalism. A real CSR would show a positive attitude towards human rights as the Unconditional Basic Income (see the Iglesias' website: www. rentabasica.net).

Milanovic and Muñoz del Bustillo (2008) cite a World Bank report which states that universal programmes with high coverage of population have a greater redistributive effect than selective ones for more disadvantaged people. Moreover, contrary to conventional wisdom, salary does not always reward underlying profitability (NEF 2009): For every pound earned by a banker, senior manager or tax advisor, society loses between 7-47 pounds and gains between 7-12 pounds if it is a childhood caretaker, cleaning staff or hospital staff.

At an inequality level, several studies conclude the importance of new ways of supra-country measures (Milanovic 2012, 2013). Statistical evidence shows increasing rates of inequality, especially in countries with conservative governments (Maravall 2013).

At a sustainability level, capitalism tries impose its neoliberal view of "sustainability" by means of conservative ecologist groups (Ehrlich vs. Commoner or conservative/Malthusian 
vs. progressive/non-Malthusian groups) ${ }^{7}$. According to O'Connor (1998: 234): “There is a worldwide struggle to determine how 'sustainable development' or 'sustainable capitalism' will be defined and used in the discourse on the wealth of nations. This means that 'sustainability', in the first place, is an ideological and political, not an ecological and economic, question". Several scholars study this topic from different methodologies (SEO/BirdLife, WWF 2010; Jackson 2011; Franco et al. 2012a).

Finally, at a social welfare level, Navarro (2011) pointed out the paradox between the defence of neoliberal policies and their negative effects on the social welfare. Other authors are Navarro (2013), García-Arias et al. (2013) and Taifa Seminary (several years).

In sum, all these levels explain the main course of the European "austericide" policies. These austerity policies favour precarious living conditions, as opposed to the sustainability promoted by feminist economics. According to Cristina Carrasco (interviewed by Abasolo, Vicent 2014), sustainability requires that social reproduction be accompanied by good living conditions. Nevertheless, sustainability is being replaced by precariousness: greater inequality, higher poverty rates, more domestic service (which affects women primarily who are still the main working force in this market). The current crisis is a sustainability crisis because it endangers, on one hand, the reproduction conditions linked to the environment and natural resources, primarily because the only proposed solution to the crisis is an economic one. On the other hand, it endangers the reproduction of people due to the undernourishment of part of the paedriatic population.

In this sense, "austericide" policies "are part of the long process of cutting back on social and working rights, privatisations and liberalisations which goes back a couple of decades and which came to the fore with European integration" (Taifa Seminary 2011: 33, 2014).

\section{Policy recommendations}

Finally, the "austericide recommendations" implemented by the Troika and their puppet national governments could be completely re-addressed if we refocus the concept of proletarians as "location migrants" to "class migrants" (not necessarily embourgeoisement). According to the dynamic of the dis-alienation process, this means less focus on studying migratory demography and a greater focus on studying class struggle. It also means less charity aid and more Human Rights observation. It means shifting from financial power to global democracy. It means going from growth to redistribution policies, less "measurement obsession" and more "permanent revolution". The world is asking for more democracy. Economic liberalism is still denying the Marxian method by using arguments based on "natural" (apolitical) crises, which reinforce the neoliberal strategy which maintains the interests of the elite. However, despite the rhetoric which tries to reduce Marx's theory to a bunch of fanciful hypotheses and nothing more than symbolic good intentions, or which tries to refute it entirely through a supposed empirical discrediting, a Marxian analysis remains relevant. This is not only due to the validity of such a theory but also because it forms the basis of class struggle in the current unsustainable global economy.

The policy implications could be reoriented from migrants to women, and from women to proletarians. Definitely, from local or particular exploitation to global exploitation. 
Gender is not a secondary element: it is implicit in social class. "If women's liberation is unthinkable without communism, then communism is unthinkable without women's liberation" (Inessa Armand, the first leader of the Women's Department of the 1917 Russian Revolution - cited by Smith 2013).

Following Baños (2009: 207): "the working class also includes child and female labour force, which has hidden through its natural silence the worst effects of exploitation. On the other hand, the working class represented by the syndicated male became the interlocutor".

We can say than gender is a structural concept in the social class category. Gender is not subordinated to social class. Without gender there is no social class (in Lacanian terms, we are sexed, speakers and mortals). Poverty and sustainability are mainly political problems and the gender gap is its quintessence: worker, migrant and... woman (Parrella 2003), the hidden abode of the worker's identity.

\section{Conclusions}

The Neoliberal Manifesto seems a great triumph: a zombie is haunting Europe, the zombie of neoliberalism. Migrants of all countries, disperse!

Do we live in a Marxian world? The Marx's method (historical, dialectical) does not propose a type of society, a mean of production, an economic system nor a policy recommendation (Arrizabalo 2014). Marx never designed how to build a socialist society. "But his way of viewing things is not a doctrine but a method. It does not provide ready-made dogmas, but criteria for further research and the method for this research" (Engels 1895).

The main conclusions can be divided in three levels: methodological, empirical and political.

On a methodological level a new re-conceptualization from the nation-states to a corporate-nation in globalization is necessary, particularly to study inequalities. Moreover, following Fraser (2014), capitalism is not only related to labour exploitation in production, we need to discover its hidden premise: its incompatibility with democracy and its unsustainability in regards to the ecological and feminist points of view, especially in capitalist crisis. Particularly, "a distinct advantage of Marxist theories of capitalist crisis is that, contrary to mainstream theories, which tend to blame the recurring crises of capitalism largely on 'external' factors, they focus on the structural dynamics of the market mechanism that tend to periodically erode capitalist profitability from within the system itself" (Hossein-Zadeh 2014b: 474).

On a empirical level, according to Dow (1998: 55): "As well as looking back to the preconditions of capitalism, Marx looked forward to the possibility of financial crisis, the concentration of industry and thus the demise of free competition, and increasing capital-labour ratios as technological changes were introduced in attempts to delay the falling profit rate, with the outcome of increasing unemployment".

On a political level, exploitation conditions are the same with $€ 5$ and with $€ 5000$. The difference lies in the degree of psychological tolerance and social and individual outrage when faced with these exploitative conditions. With $€ 5000$ the legitimacy of economic capitalism is more powerful than the conscience of the exploited individual. On the other 
hand, with $€ 5$ capitalism's ideological legitimacy and ability to repress is weaker than the social awareness of being exploited.

For the above, a Marxian strategy for a gradual process of global dis-alienation is described in Table 3, according to different dimensions: economic, social, moral and global. This strategy is based on the main Marxian categories of analysis (private property, capitalist accumulation, labour exploitation, class struggle and revolutionary conscience). They are linked to Maslow's Pyramid, the different moral development of men and women, and several models of sustainability, solidarity and responsibility.

Table 3. Marxian methodology for a global dis-alienation process

\begin{tabular}{|c|c|c|c|c|c|c|}
\hline $\begin{array}{l}\text { Dimen- } \\
\text { sion }\end{array}$ & Author & Level 1 & Level 2 & Level 3 & Level 4 & Level 5 \\
\hline Global & $\begin{array}{l}\text { Marx } \\
(1998)\end{array}$ & $\begin{array}{l}\text { Private } \\
\text { property }\end{array}$ & $\begin{array}{l}\text { Capitalist ac- } \\
\text { cumulation }\end{array}$ & $\begin{array}{l}\text { Labour } \\
\text { exploitation }\end{array}$ & $\begin{array}{l}\text { Class } \\
\text { struggle }\end{array}$ & $\begin{array}{l}\text { Conscience of } \\
\text { revolutionary } \\
\text { class }\end{array}$ \\
\hline \multirow{2}{*}{$\begin{array}{l}\text { Eco- } \\
\text { nomic }\end{array}$} & $\begin{array}{l}\text { Maslow } \\
(1943)\end{array}$ & $\begin{array}{l}\text { Physiological } \\
\text { needs }\end{array}$ & Safety needs & Social needs & Esteem needs & Self-actualization \\
\hline & $\begin{array}{l}\text { O'Connor } \\
\text { (1998) }\end{array}$ & $\begin{array}{l}\text { Survival of } \\
\text { capitalism }\end{array}$ & $\begin{array}{l}\text { Sustainable } \\
\text { growth }\end{array}$ & $\begin{array}{l}\text { Progressive } \\
\text { ecology }\end{array}$ & $\begin{array}{l}\text { Stronger } \\
\text { unions }\end{array}$ & $\begin{array}{l}\text { More } \\
\text { democracy }\end{array}$ \\
\hline \multirow[b]{2}{*}{ Social } & $\begin{array}{l}\text { Aranguren } \\
(1998)\end{array}$ & Show & Campaign & Volunteer & $\begin{array}{l}\text { Pseudo-Co- } \\
\text { operation }\end{array}$ & $\begin{array}{l}\text { Human } \\
\text { Rights }\end{array}$ \\
\hline & $\begin{array}{l}\text { Herzig, } \\
\text { Moon } \\
(2013)\end{array}$ & $\begin{array}{l}\text { Market ratio- } \\
\text { nalization }\end{array}$ & $\begin{array}{l}\text { Moralization } \\
\text { and ethical } \\
\text { leadership }\end{array}$ & $\begin{array}{l}\text { Reconceptua- } \\
\text { lization and } \\
\text { professionali- } \\
\text { zation }\end{array}$ & $\begin{array}{l}\text { Political } \\
\text { economy } \\
\text { restructuring } \\
\text { (reformist) }\end{array}$ & $\begin{array}{l}\text { Political econo- } \\
\text { my restructuring } \\
\text { (radical change) }\end{array}$ \\
\hline \multirow[b]{2}{*}{ Moral } & $\begin{array}{l}\text { Kohlberg } \\
(1981)\end{array}$ & $\begin{array}{l}\text { Pre-conven- } \\
\text { tional }\end{array}$ & Heteronomy & Conventional & $\begin{array}{l}\text { Post-conven- } \\
\text { tional }\end{array}$ & Autonomy \\
\hline & $\begin{array}{l}\text { Gilligan } \\
(1982)\end{array}$ & $\begin{array}{l}\text { Survival } \\
\text { of Ego }\end{array}$ & $\begin{array}{l}\text { Transition } \\
\text { phase }\end{array}$ & $\begin{array}{l}\text { Responsibi- } \\
\text { lity towards } \\
\text { others }\end{array}$ & $\begin{array}{l}\text { Transition } \\
\text { phase }\end{array}$ & $\begin{array}{l}\text { Responsibility } \\
\text { of care }\end{array}$ \\
\hline
\end{tabular}

Source: Our own from several authors.

New research is necessary in order to dig deeper into this theoretical framework on global irresponsibility, global labour exploitation and the global dis-alienation process, particularly linked to the financialization process and its connexion to a non-patriarchal, post-capitalist society based on real democracy.

\section{Notes}

1. There is a main difference between "Marxian" and "Marxist" concepts. "Marxian" is a more technical term related to Marx's written only. "Marxist" is a wider concept, more related to documents, approaches and traditions by Marx and followers.

2. Milanovic and Muñoz del Bustillo (2008) pointed out that in Latin America the class component (within-country inequalities) is greater than the location component (between-country inequalities). Surprisingly, with Milanovic (2013) the contrary could be 
implied. Although there is also a methodological error: the "average problem", particularly when income inequalities are very heterogeneous. A more accurate measurement should be the median, not the mean. The national average is not the most representative measure, particularly in countries with a high polarization of income distribution. For example, Spain presents a Gini's index with a class component higher than what is used to describe average European countries. In India two thirds of poor people live in low income provinces and one third lives in middle income provinces (Sumner 2012), although the average income is classified as middle income country ("poverty paradox"). Another example, with big repercussions for the economic theory related to the Giffen behaviour, can be seen in Franco (2015).

3. This idea suggests a connection with the methodological and epistemological studies by feminist economics (Orozco 2005). Also Sheila Dow's Modes of Thought Theory and her classification in the Cartesian/Euclidean (thesis), non-Cartesian/Euclidean (anti-thesis) and Babylonian (synthesis) thoughts (Dow 1998).

4. More details in the next link by International Organization for Migration: www.iom.int/ $\mathrm{cms} / \mathrm{en} / \mathrm{sites} /$ iom/home/about-migration/facts--figures-1.html

5. These concepts are mainly a re-actualization of the invisible hand principle. Philanthrocapitalism is coined in a 2006 Economist magazine article, the concept is developed most fully in Bishop, Green (2008). While "market populism" is related to the global triumph of markets (Frank 2001: 55).

6. The Base Of the Pyramid (BOP) proposition holds that transnational corporations can profitably and ethically serve the needs of the poor at the base of the global economic pyramid, 4 billion people below $\$ 9.05$ per day, $70.18 \%$ of world population (Arnold, Valentin 2013).

7. Barry Commoner was the pioneer of progressive ecology in USA. He criticized Paul Ehrlich's Malthusian ecological view. For more details see the posts by Vicenç Navarro dated 15/10/2012 and 30/07/2014 in his website: www.vnavarro.org

\section{Acknowledgements}

The author is grateful to the referees for their valuable comments. Their suggestions and corrections have improved this article considerably. The translation of this paper was partially supported by Junta de Extremadura and European Regional Development Fund (project GR15126) through the DELSOS Research Group from University of Extremadura.

\section{References}

Abasolo, O.; Vicent, L. 2014. Entrevista a Cristina Carrasco, Papeles de Relaciones Ecosociales y Cambio Global 127: 141-156 (in Spanish).

Agüera, J. M.; García-Arias, J. 2000. Distorsiones del sistema financiero internacional. Un Impuesto sobre las Transacciones Financieras en Divisas como alternativa, Revista de Economía Mundial 2: 9-39 [online], [cited 01 June 2014]. Available from Internet: http://hdl.handle.net/10272/358 
Aranguren, L. A. 1998. Interrogando la solidaridad, Vida Nueva 2144: 23 -29 (in Spanish).

Arnold, D. G.; Valentin, A. 2013. Corporate social responsibility at the base of pyramid, Journal of Business Research 66: 1904-1914. https://doi.org/10.1016/j.jbusres.2013.02.012

Arnsperger, C.; Varoufakis, Y. 2006. What Is Neoclassical Economics? The three axioms responsible for its theoretical oeuvre, practical irrelevance and, thus, discursive power, Panoeconomicus 1: 5-18. https://doi.org/10.2298/PAN0601005A

Arrizabalo, X. 2014. Capitalismo y economía mundial. Instituto Marxista de Economía, Madrid.

Ayers, A. J.; Saad-Filho, A. 2015. Democracy against neoliberalism: paradoxes, limitations, transcendence, Critical Sociology 41(4-5): 597-618. https://doi.org/10.1177/0896920513507789

Banerjee, A. V.; Duflo, E. 2011. Poor economics: a radical rethinking of the way to fight global poverty. New York, NY: Public Affairs.

Baños, A. 2009. La economía no existe. Barcelona: Los libros del lince.

Benería, L. 2008. The crisis of care, international migration and public policy, Feminist Economics 14(3): 1-22. https://doi.org/10.1080/13545700802081984

Bishop, M.; Green, M. 2008. Philanthrocapitalism: how the rich can save the world. New York, NY: Bloomsbury Press.

Buendía, L.; Palazuelos, E. 2014. Economic growth and welfare state: a case study of Sweden, Cambridge Journal of Economics 38(4): 761-777. https://doi.org/10.1093/cje/bet049

Burchardt, T. 2008. Time and income poverty. CASE report 57 [online], [cited 01 June 2014]. London School of Economics. Available from Internet: http://sticerd.lse.ac.uk/case/publications/reports.asp

CECS. 2011. Informe España 2011. Report. Centro de Estudios del Cambio Social, Fundación Encuentro, Madrid. $117 \mathrm{p}$.

CGT. 2004. Precariedad y cuidados. Materiales de Formación, Cuaderno 3, Confederación General de Trabajadores, Madrid. 43 p.

Colectivo Ioé. 2001. Una aproximación descriptiva a la situación de la inmigración ecuatoriana en España: Los trabajadores del servicio doméstico. Informe 4. Colectivo Ioé, Madrid. 29 p.

Consumers International. 2010. Hora de pasar por caja. Report. Consumers International, London. $64 \mathrm{p}$.

Cortina, A. 2011. Neuroética y neuropolítica. Madrid: Tecnos.

De Sebastián, L. 2000. Capitalismo y democracia en el siglo XXI. Cuadernos 99. Fundación Luis Espinal, Barcelona. $32 \mathrm{p}$.

Dow, S. C. 1998. The methodology of macroeconomic thought. Cheltenham: Edward Elgar Publishing.

Duménil, G.; Lévy, D. 2011. The crisis of neoliberalism. Cambridge, Massachusetts: Harvard University Press.

Duménil, G.; Lévy, D. 2014. La grande bifurcation. En finir aver le néolibéralisme. Paris: La Découverte.

Engels, F. 1895. Letters: Engels to Sombart, 11/03/1895 [online], [cited 12 March 2015]. Available from Internet: https://www.marxists.org/archive/marx/works/1895/letters/95_03_11.htm

Etxezarreta, M. 2012. Dentro del sistema no hay solución: Reflexionando sobre las alternativas al capitalismo, in Ciclo de Conferencias de Ecología y Medio Ambiente, 9 March 2012, Córdoba, Spain.

Federici, S. 2004. Caliban and the witch. Brooklyn, NY: Autonomedia.

Franco, J. A. 2015. Principles of Economethics from the Giffen demand, Technological and Economic Development of Economy 21(4): 557-576. https://doi.org/10.3846/20294913.2013.876686

Franco, J. A.; Cascante, K. 2012. Structural dimension of financial speculation on food demand, in $I$ Congress of REEDES, 14-16 November 2012, Santander, Spain. 
Franco, J. A.; Gaspar, P.; Mesías, F. J. 2012a. Economic analysis of scenarios for the sustainability of extensive livestock farming in Spain under the CAP, Ecological Economics 74(1): 120-129. https://doi.org/10.1016/j.ecolecon.2011.12.004

Franco, J. A.; Rodríguez, M.; Rodríguez, M. J. 2012b. The ordination of women in the Catholic Church: a survey of attitudes in Spain, Journal of Gender Studies 21(1): 17-34. https://doi.org/10.1080/09589236.2012.641391

Frank, T. 2001. One market under god. New York, NY: Anchor Books.

Fraser, N. 2014. Behind Marx's hidden abode, New Left Review 86: 55-72.

Gálvez, L.; Torres, J. 2010. Desiguales. Mujeres y hombres en la crisis financiera. Barcelona: Icaria.

García-Arias, J. 2015. International financialization and the systemic approach to international financing for development, Global Policy 6(1): 24-33. https://doi.org/10.1111/1758-5899.12143

García-Arias, J.; Fernández-Huerga, E.; Salvador, A. 2013. European periphery crises, international financial markets and democracy, American Journal of Economics and Sociology 72(4): 826-850. https://doi.org/10.1111/ajes.12031

García-Moreno, C. 2015. Trayectorias laborales de las mujeres migrantes cubanas en España, Migraciones Internacionales 8(1): 189-219.

Gilligan, C. 1982. In a different voice. 1993 edition. Cambridge, Massachusetts: Harvard University Press.

Glennie, J. 2012. What if three quarters of the world's poor live (and have always lived) in Low Aid Countries? Background Note. Overseas Development Institute, London. 6 p.

Gómez, J. D.; Franco, J. A. 2014. La agenda oculta de la cooperación al desarrollo, Chapter 4 in J. J. Losada, J. C. Barrera (Eds.). Lecturas Críticas del Desarrollo: Perspectivas Latinoamericanas. Bogotá: Editorial Bonaventuriana, 129-152.

Guerrero, D. 2008. Un resumen completo de El Capital de Marx. Madrid: Maia Editores.

Herzig, C.; Moon, J. 2013. Discourses on corporate social ir/responsibility in the financial sector, Journal of Business Research 66: 1870-1880. https://doi.org/10.1016/j.jbusres.2013.02.008

Hossein-Zadeh, I. 2014a. Keynes is dead; long live Marx!, CounterPunch, 26 August 2014 [online], [cited 26 August 2014]. Available from Internet: www.counterpunch.org/2014/08/26/keynes-isdead-long-live-marx/

Hossein-Zadeh, I. 2014b. Flaws in the Marxian Explanations of the Great Recession, Review of Radical Political Economics 46(4): 473-480. https://doi.org/10.1177/0486613414537983

Hudson, D. 2008. Developing geographies of financialisation: banking the poor and remittance securitization, Contemporary Politics 14(3): 315-333. https://doi.org/10.1080/13569770802396360

Iglesias, J.; Badenes, X. 2011. Apuntes sobre la economía furtiva del capitalismo, Informes de Economía Crítica 8: 42-59 (in Spanish).

ILO. 2015. Ratifications of C189 [online], [cited 16 March 2015]. International Labour Organization. Available from Internet: www.ilo.org/dyn/normlex/en/f?p=NORMLEXPUB:11300:0::NO::P11300_ INSTRUMENT_ID:2551460

Jackson, T. 2011. Prosperity without growth? Routledge. 288 p.

Klein, N. 2008. The shock doctrine: the rise of disaster capitalism. New York, NY: Picador.

Kohlberg, L. 1981. The philosophy of moral development. San Francisco, CA: Harper and Row.

Maravall, J. M. 2013. Las promesas politicas. Barcelona: Galaxia Gutenberg.

Marx, K. 1868. Marx-Engels correspondence 1868: Marx to Ludwig Kugelmann in Hannover, London 12 December 1868 [online], [cited 17 February 2015]. Available from Internet: https://marxists.anu. edu.au/archive/marx/works/1868/letters/68_12_12.htm 
Marx, K. 1998. El Capital, vol. 1. Madrid: Siglo XXI.

Maslow, A. H. 1943. A theory of human motivation, Psychological Review 50(4): 370-396. https://doi.org/10.1037/h0054346

McGoey, L. 2012. Philanthrocapitalism and its critics, Poetics 40: 185-199. https://doi.org/10.1016/j.poetic.2012.02.006

Medina, J. M.; Cascante, K. 2011. Especulación financiera y crisis alimentaria. Report. Madrid: Ayuda en Acción, Cáritas Española, Ongawa, Prosalus. 113 p.

Milanovic, B. 2012. Global inequality: from class to location, from proletarians to migrants, Global Policy 3(2): 125-134. https://doi.org/10.1111/j.1758-5899.2012.00170.x

Milanovic, B. 2013. Global income inequality in numbers: in history and now, Global Policy 4(2): 198-208. https://doi.org/10.1111/1758-5899.12032

Milanovic, B.; Muñoz del Bustillo, R. 2008. La desigualdad de la distribución de la renta en América Latina, América Latina Hoy 48: 15-42 (in Spanish).

Narayan, D.; Chambers, R.; Shah, M. K.; Petesch, P. 2000. Voices of the poor: crying out for change. New York, NY: Oxford University Press. https://doi.org/10.1596/0-1952-1602-4

Navarro, V. 2011. El fracaso del neoliberalismo en el mundo y la Unión Europea, Ola Financiera 10: 95-116 (in Spanish).

Navarro, V. 2012. El por qué de los recortes, Diario Público, 12 July 2012 [online], [cited 01 June 2014]. Available from Internet: http://blogs.publico.es/dominiopublico/5499/el-por-que-de-los-recortes/

Navarro, V. 2013. ¿Qué pasa en Suecia?, El Plural.com, 09 June 2013 [online], [cited 01 June 2014]. Available from Internet: http://www.elplural.com/opinion/que-pasa-en-suecia/

Navarro, V.; Torres, J. 2012. Los amos del mundo. Madrid: Espasa.

NEF. 2009. A bit rich. Report. The New Economics Foundation, London. 44 p.

O'Connor, J. 1998. Natural causes. Essays on ecological marxism. New York, NY: The Guilford Press.

Orozco, A. 2005. Economía del género y economía feminista, ¿conciliación o ruptura?, Revista Venezolana de Estudios de la Mujer 10(24): 43-63 (in Spanish).

Ortiz, I.; Burke, S.; Berrada, M.; Cortés, H. 2013. World Protests 2006-2013. Working Paper. Initiative for Policy Dialogue, Friedrich-Ebert-Stiftung, New York. 91 p.

Oxfam. 2002. Rigged rules and double standards. Report. Oxfam Great Britain, Oxford. 276 p.

Parrella, S. 2003. Mujer, inmigrante y trabajadora: la triple discriminación. Barcelona: Anthropos.

Pérez de Armiño, K. 2011. Crisis alimentaria y lucha contra el hambre en el África Subsahariana. La cuestionable contribución de los ODM, Revista de Economía Mundial 27: 117-148 (in Spanish).

Ramos, L. 2006. Los crímenes de la deuda. Deuda ilegítima. Barcelona: Icaria.

Rifkin, J. 2014. The zero marginal cost society: the internet of things, the collaborative commons, and the eclipse of capitalism. New York, NY: Palgrave Macmillan.

Sarasúa, C. 1994. Criados, nodrizas y amos. Madrid: Siglo XXI.

Sassen, S. 1999. Globalization and its discontents. New York, NY: The New Press.

SEO/BirdLife; WWF España. 2010. ¿Quien contamina cobra?: Relación entre la PAC y el medioambiente en España. Report. Sociedad Española de Ornitología/BirdLife, World Wide Fund For Nature España, Madrid. 32 p.

Smith, S. 2013. Marxism, feminism and women's liberation, Socialist Worker, 31 January 2013 [online], [cited 17 February 2015]. Available from Internet: http://socialistworker.org/2013/01/31/marxismfeminism-and-womens-liberation

Sumner, A. 2012. Where do the world's poor live? A new update. IDS Working Paper 393. Institute of Development Studies, Brighton, UK. 27 p. 
Swift, J. 1729. A modest proposal. 2005 ed. Renascence editions [online], [cited 01 June 2013]. Available from Internet: https://scholarsbank.uoregon.edu/xmlui/bitstream/handle/1794/872/modest.pdf

Taifa Seminary. 2011. La estrategia del capital, Informes de Economía Crítica 8. Seminarios de Economía Crítica Taifa, Barcelona. 60 p.

Taifa Seminary. 2013. Reflexionando sobre las alternativas, Informes de Economía Crítica 9. Seminarios de Economía Crítica Taifa, Barcelona. 126 p.

Taifa Seminary. 2014. Desentrañando la Unión Europea, Informes de Economía Crítica 10. Seminarios de Economía Crítica Taifa, Barcelona. 112 p.

Taifa Seminary (several years). Reports about Critical Economy [online], [cited 10 February 2014]. Seminarios de Economía Crítica Taifa. Available from Internet: http://informes.seminaritaifa.org/

UN. 2009. Trends in international migrant stock: the 2008 revision [online], [cited 12 April 2014]. United Nations. Available from Internet: http://esa.un.org/migration/index.asp?panel=1

UNFPA. 2006. State of World population 2006. Report. United Nations Population Fund, New York. $116 \mathrm{p}$.

Van Staveren, I. 2010. Post-Keynesianism meets feminist economics, Cambridge Journal of Economics 34(6): 1123-1144. https://doi.org/10.1093/cje/ben033

Van Staveren, I. 2014. The Lehman Sisters hypothesis, Cambridge Journal of Economics 38(5): 995-1014. https://doi.org/10.1093/cje/beu010

WEF. 2014. The global gender gap report 2014. World Economic Forum, Geneva.

J. Agustín FRANCO is Associate Professor of Economics at the University of Extremadura, Spain. He defended his Doctoral Thesis on Economy at the University of Córdoba in 2009. He was Assistant Professor at the University of Zaragoza from 2006 to 2009. He is author of several papers in the field of natural resources and agrarian sciences. His research focuses on applied economy, mainly environmental and gender studies, from a heterodox view. 